\title{
PATHOGENESIS OF MENINGOENCEPHALITIS IN RABBITS BY BOVINE HERPESVIRUS TYPE-5 (BHV-5)
}

\author{
Adriana M. da Silva ${ }^{1}$, Eduardo F. Flores ${ }^{2 *}$, Rudi Weiblen ${ }^{2}$, Marister C. Canto ${ }^{1}$, Luiz F. Irigoyen ${ }^{3}$, \\ Paulo M. Roehe ${ }^{4}$, Renato S. de Sousa ${ }^{5}$ \\ ${ }^{1}$ Departamento de Medicina Veterinária Preventiva-DMVP, ${ }^{2}$ Microbiologia e Parasitologia/DMP, \\ ${ }^{3}$ Departamento de Patologia da Universidade Federal de Santa Maria-UFSM. Santa Maria, RS, Brasil. \\ ${ }^{4}$ Centro de Pesquisas Veterinárias Desidério Finamor (CPVDF), Eldorado do Sul, RS, Brasil and \\ Departamento de Microbiologia. Universidade Federal do Rio Grande do Sul, Porto Alegre, RS, Brasil. \\ ${ }^{5}$ Universidade do Estado de Santa Catarina, Centro de Pesquisas Agroveterinárias, Lages, SC, Brasil.
}

Submitted: May 13, 1998; Returned to authors for corrections: September 24, 1998; Approved: April 06, 1999

\begin{abstract}
This article describes the main aspects of bovine herpesvirus type-5 (BHV-5) neurologic infection and disease in rabbits, a candidate animal model for studying BHV-5 neuropathogenesis. Intranasal inoculation of weanling rabbits with a Brazilian BHV-5 isolate produced neurological disease and death in $78.8 \%(26 / 33)$ of the animals. Neurological signs started as early as 5 days post-inoculation and lasted from 10-12 hours up to several days. Most animals evolved to a moribund state or death within 24 $(69.2 \%)$ to 48 hours $(88.5 \%)$. Neurological disease was characterized by excitability or depression, tremors, bruxism, walking or running in circles, backward arching of the head and body, incoordination, backward and sideways falling, paddling, profound depression and death. Moderate levels of infectivity were detected in several areas of the brain, most consistently in the ventro-lateral hemisphere (in 16 out of 20 animals), anterior cerebrum (15/20), midbrain (11/20), dorso-lateral hemisphere (10/20) and pons (12/ 26). Infectious virus was also recovered from the olfactory bulb $(9 / 20)$, medulla oblongata $(10 / 26)$, cerebellum $(7 / 20)$, posterior cerebrum $(5 / 20)$ and trigeminal ganglia $(4 / 20)$. No gross lesions were observed. Microscopic lesions were mild and consisted of nonsuppurative meningitis, mononuclear perivascular cuffing and focal gliosis. These changes were observed most consistently in the ventro-lateral hemisphere and anterior cerebrum. Passive immunity partially protected rabbits from BHV-5-induced encephalitis. Rabbits born to immunized dams showed a significative delay in the onset of clinical disease and reduced morbidity and mortality rates compared to rabbits born to unvaccinated dams. These results demonstrate that BHV-5-induced neurological disease can consistently be reproduced in rabbits and point towards the use of this species as an animal model to study BHV-5 neuropathogenesis.
\end{abstract}

Key words: Bovine herpesvirus type-5, BHV-5, meningoencephalitis, rabbits, animal model

\footnotetext{
* Corresponding author. Mailing address: Departamento de Medicina Veterinária Preventiva, DMVP - Universidade Federal de Santa Maria, CEP 97105-900, Santa Maria, RS, Brasil. Fax: (+5555) 220-8257. E-mail: flores@ccr.ufsm.br
} 


\section{INTRODUCTION}

Previously classified as bovine herpesvirus type1.3 (BHV-1.3), the alphaherpesviruses causing meningoencephalitis in cattle have been recently reclassified as bovine herpesvirus type-5 (BHV-5) (24) or bovine encephalitis herpesvirus (BEHV)(27). These neuropathogenic viruses are closely related to the respiratory and genital BHV-1 strains (BHV-1.1 and BHV-1.2, respectively) in many molecular and biological aspects $(4,6,11,18,29)$. However, they can be differentiated from the classical BHV-1 strains by DNA restriction endonuclease analysis $(6,18)$, reactivity with monoclonal antibodies $(11,18,23)$, and differential expression of virus-encoded polypeptides $(11,18)$. The major difference between BHV-5 and BHV-1, however, relates to their distinct ability to invade the central nervous system (CNS) and cause neurological disease $(2,3)$. Whereas BHV5 has commonly been associated with meningoencephalitis in cattle, isolation of BHV-1 has been largely restricted to respiratory and genital disease $(2,12,13,25,27)$.

The biological and molecular basis for the neuropathogenic phenotype of BHV-5 are poorly understood. This is due, in part, to the lack of a suitable animal model to study the neuropathogenesis of BHV5 infections. The pathogenesis of neurological infections by two other neurotropic alphaherpesviruses, herpes simplex virus (HSV) and pseudorabies virus (PRV), has been largely studied in mice $(1,17,26,28)$ and rats $(7,8,9)$. In contrast, studies on the pathogenesis of BHV-5 have been restricted to cattle $(2,3,13)$. Fruitless attempts to reproduce the BHV-5-induced neurological disease in rabbits have been reported since the initial identification of BHV-5 as a causative agent of bovine meningoencephalitis (13). In contrast, rabbits have been used to study selected aspects of acute and latent infections by BHV-1 $(21,22)$. Only after the description of a special technique for intranasal inoculation (5), BHV-5 infection and disease have been reproduced in rabbits $(10,19)$.

The main purpose of this study was to investigate the susceptibility of rabbits to infection and disease with a Brazilian BHV-5 isolate. Intranasal inoculation of weanling rabbits with BHV-5 EVI- 88 strain consistently resulted in viral invasion of the CNS and neurological disease. Moreover, the rabbit infection and disease resembled in many aspects the experimental and naturally occurring disease in cattle.
Further studies are underway to better characterize the rabbits infection and disease by BHV-5 and to evaluate the suitability of rabbits as an animal model to study selected aspects of BHV-5 neuropathogenesis.

\section{MATERIALS AND METHODS}

Experimental Design. Three animal inoculations were performed to evaluate the susceptibility of rabbits to BHV-5 and to initially characterize the neurological disease associated with BHV-5 infection (Table 1). Weanling rabbits were inoculated intranasally with a Brazilian BHV-5 isolate and submitted to virological and clinical monitoring. Necropsies were performed in animals recently dead or euthanized in extremis. Tissue samples collected at necropsy were submitted to virus isolation and histological examination. A fourth experiment was conducted to evaluate the ability of passive immunity in preventing BHV-5-induced neurological disease. Two adult female rabbits were immunized twice with the homologous BHV-5 (days 0 and 15) and mated 15 days later. Rabbits born to immunized and nonimmunized dams were inoculated at weaning and the course of clinical disease and morbidity/mortality rates were compared (Table 4).

Cell culture and virus. The BHV-5 isolate EVI88 was obtained from calves with clinical meningoencephalitis in Mato Grosso do Sul state, Brazil, and partially characterized by Roehe et al. (23). The Argentinean isolate (A663), utilized in preliminary experiments, was provided by Dr. Laura Weber, INTA Castelar, Argentina. Madin-Darby bovine kidney cells (MDBK) were used for all procedures of virus multiplication, quantitation and isolation from tissues. Cells were routinely maintained in Eagle s minimal essential medium (MEM) containing penicillin $(1.6 \mathrm{mg} / \mathrm{l})$, streptomycin $(0.4 \mathrm{mg} / \mathrm{l})$, supplemented with fetal calf serum (Cultilab). The virus titers used for each animal inoculation are presented in Table 1. Adult female rabbits were immunized by two inoculations (15 days apart) with $10^{7.31} \mathrm{TCID}_{50}$ of virus. In the experiment of passive immunity (\#4), rabbits were challenged with $10^{8.22} \mathrm{TCID}_{50}$ of virus.

Rabbits and animal inoculation. Four to fiveweeks-old, recently weaned New Zealand or Chinchilla rabbits (weighing approximately 0.3 to 0.4 $\mathrm{kg}$ ) were used throughout the experiments. Rabbits were maintained in collective cages and given food and water ad libitum. Experiment \# 4 utilized three 
adult female rabbits (two of which were immunized with BHV-5) and their offspring. In experiment \# 1, six rabbits (three virus-inoculated and three uninfected controls) were treated with dexamethasone (Azium, Schering-Plough, $0.4 \mathrm{mg} /$ animal/day) during 5 days before virus inoculation. Prior to virus inoculation, rabbits were anesthetized by intramuscular administration of $0.2 \mathrm{ml}$ (2mg) of Zoletil (Virbac). Rabbits were inoculated into the paranasal sinuses through nephrine openings according to a protocol adapted from Brown and Field (5). Each weanling rabbit was inoculated with $0.5 \mathrm{ml}$ of viral suspension in each nostril. After inoculation, the heads were maintained upwards for a few seconds to allow an uniform distribution of the inoculum in the nasal cavity. The adult female rabbits were immunized by intramuscular and intranasal inoculation of virus suspension, as described above.

Monitoring and sample collection. Rabbits were monitored clinically three times a day until the onset of clinical signs. Thereafter, monitoring was performed several times a day, in an almost continuous basis. Nasal swabs for viral isolation were collected every two days in the two first experiments. Nasal swab specimens $(0.2 \mathrm{ml})$ were inoculated onto MDBK cells grown in 24 well plates and monitored for cytopathic effect (CPE) during 5 days. Negative samples were further inoculated onto fresh MDBK cell monolayers and monitored for additional 5 days. Blood for serology was collected from all inoculated rabbits before virus inoculation. Rabbits were tested for BHV-5 neutralizing antibodies prior to virus inoculation and females were tested at day 0 , day of mating (day 30) and at the day of weaning (day 90). Serum samples were submitted to a standard microtiter virus-neutralizing (VN) assay (4), using two-fold dilutions of serum against a fixed dose of virus (100$200 \mathrm{TCID}_{50} /$ well).

Tissue samples for viral isolation and histologic examination were collected at necropsy performed in rabbits euthanized in extremis or recently dead. Different sections of CNS (Tables 3 and 4), plus lungs, liver, spleen and kidney were aseptically collected and submitted to virus isolation. Tissue samples for virus isolation were processed by preparing a $10 \%(\mathrm{wt} / \mathrm{vol})$ homogenized suspension and inoculated onto MDBK cell monolayers grown in $24 /$ well plates. Monitoring of CPE was performed as described above. Samples positive for $\mathrm{CPE}$ were subsequently quantitated by inoculating 10-fold dilutions onto MDBK cells cultivated in 96/well plates. Virus titers were calculated according to Reed and Muench (20) and expressed as $\log _{10} \mathrm{TCID}_{50} / \mathrm{g}$ of tissue. Tissues for histopathologic examination were fixed in $10 \%$ formalin, embedded in paraffin, sectioned and stained with hematoxylin-eosin (HE), using routine methods.

\section{RESULTS}

Morbidity and mortality. Inoculation of weanling rabbits with the Brazilian isolate EVI-88 produced neurological disease in $25(75.8 \%)$ and death in $26(78.8 \%)$ of the inoculated animals (Table 1). All the animals showing neurological signs evolved to a moribund state or death. In contrast, six rabbits inoculated with an Argentinean isolate (A663) remained healthy in spite of an efficient viral replication detected in the nasal mucosa for up to 8 days (data not shown). No differences in morbidity, mortality or clinical evolution were observed between

Table 1. Morbidity and mortality in weanling rabbits inoculated intranasally with bovine herpesvirus type-5 (BHV-5) strain EVI-88

\begin{tabular}{ccllcc}
\hline Experiment \# & Virus titer $\left(\right.$ TCID $\left._{50}\right)$ & Breeding & Treatment & Neurological Disease & Mortality \\
\hline 1 & $10^{7.59}$ & New Zealand & DX ${ }^{\text {a }}$ virus & $3 / 3$ & $3 / 3$ \\
& & & virus & $3 / 3$ & $3 / 3$ \\
& Controls $^{\mathrm{b}}$ & & DX+MEM & $0 / 3$ & $0 / 3$ \\
& & & MEM & $0 / 3$ & $0 / 3$ \\
2 & $10^{8.89}$ & New Zealand & virus & $6 / 7$ & $7 / 7$ \\
& $10^{8.89}$ & Chinchilla & virus & $6 / 10$ & $6 / 10$ \\
3 & Controls & & MEM & $0 / 2$ & $0 / 2$ \\
& $10^{8.22}$ & New Zealand & virus & $7 / 10$ & $7 / 10$ \\
Total (virus inoculated) & & MEM & $0 / 2$ & $0 / 2$ \\
\hline
\end{tabular}

${ }^{a}$ Animals were treated with dexamethasone $(0.4 \mathrm{mg} / \mathrm{animal} /$ day $)$ during five days prior to virus inoculation.

${ }^{\mathrm{b}}$ Control animals were inoculated intranasally with minimal essencial medium (MEM). 
the groups treated and untreated with dexamethasone (experiment \# 1). Some differences in morbidity and mortality rates were observed among the inoculations. In experiment \# 2, one rabbit was found dead without previous neurological signs. None of the control MEM-inoculated rabbits showed any clinical manifestation (Table 1).

Neurological disease. The clinical features of the neurological disease induced by BHV-5 were very similar all across the inoculations, with minor differences in the onset of clinical signs and in duration of clinical disease (Table 2). Neurological signs started between days 5 ( $9 / 25$ animals, $36 \%)$, day $6(13 / 25$ animals, $52 \%)$ and 7 pi (3/25 animals, $12 \%)$ and lasted from 10-24 h (18/25 animals, $72 \%), 48 \mathrm{~h}$ $(5 / 25$ or $19.2 \%)$ to several days ( 2 animals, $8 \%)$. Most rabbits $(88.4 \%)$ were euthanized in extremis or found dead within the first 24 to $48 \mathrm{~h}$ of clinical manifestations (Table 2). Clinical disease was characterized by periods of depression or excitability, crisis of tremors, bruxism, running in circles, backward arching of the head and body, flexion of the neck, incoordination, sideways and backways falling, profound depression and paddling. The evolution of clinical disease was characterized by a gradual yet progressive increase in the intensity and frequency of such crises. A few rabbits showed a prolonged clinical course, presenting mild and intermittent clinical signs. All animals showing neurological disease died or were euthanized in extremis; no recovery from disease was observed. Three animals (one in experiment \# 2 and two born to vaccinated dams, experiment \# 4) were found dead without previous neurological signs.

Infectivity in nasal secretions and tissues. Infectivity was detected in nasal secretions collected up to days 6 and 8 pi, in experiments \# 1 and 2, respectively. After day 8 , monitoring of viral shedding

Table 2. Clinical, virological and histological findings in rabbits which developed neurological disease following inoculation with bovine herpesvirus type 5 (BHV-5) strain EVI-88

\begin{tabular}{|c|c|c|c|c|}
\hline $\begin{array}{c}\text { Exp/ } \\
\text { animal }\end{array}$ & $\begin{array}{r}\text { Net } \\
\text { dise } \\
\text { Onset/De }\end{array}$ & $\begin{array}{l}\text { jical } \\
\text { dpi) } \\
\text { uthanasiac }^{c}\end{array}$ & $\begin{array}{l}\text { Virus in } \\
\text { the brain }\end{array}$ & Histopathology \\
\hline$\# 1.1$ & 6 & $7^{c}$ & $\mathrm{cc}, \mathrm{p}, \mathrm{cb}$ & Perivascular mononuclear cuffing $\left(+^{\mathrm{d}}\right)$ \\
\hline 2 & 6 & $7^{\mathrm{c}}$ & $\mathrm{cc}, \mathrm{p}, \mathrm{cb}$ & - \\
\hline 3 & 6 & $7^{\mathrm{c}}$ & $\mathrm{cc}, \mathrm{p}, \mathrm{cb}$ & - \\
\hline 4 & 6 & $7^{\mathrm{c}}$ & $\mathrm{cc}, \mathrm{p}, \mathrm{cb}$ & Perivascular mononuclear cuffing $(+)$ \\
\hline 5 & 6 & $7^{\mathrm{c}}$ & $\mathrm{cc}, \mathrm{p}, \mathrm{cb}$ & - \\
\hline 6 & 6 & $7^{\mathrm{c}}$ & $\mathrm{cc}, \mathrm{p}, \mathrm{cb}$ & $n e^{e}$ \\
\hline$\# 2.1$ & 7 & $12^{\mathrm{c}}$ & $\mathrm{ac}$ & - \\
\hline 2 & 6 & $6^{\mathrm{b}}$ & ac, vlh, dlh, ol & Mononuclear cell infiltrate $(+)(\mathrm{vlh})$, focal gliosis $(++)(\mathrm{mo}, \mathrm{vlh})$ \\
\hline 3 & 5 & $6^{\mathrm{c}}$ & ac, vlh, p, ol & Multifocal gliosis $(+)(\mathrm{ac})$ \\
\hline 4 & 6 & $6^{c}$ & vlh, mb, p, ol & Multifocal hemmorrhage, congestion $(+)(\mathrm{vlh})$ \\
\hline 5 & - & $13^{\mathrm{b}}$ & vlh, dlh, p, cb & ne \\
\hline 6 & 7 & $8^{c}$ & ac, vlh, mo, mb & Multifocal gliosis $(+)(\mathrm{vlh})$ \\
\hline 7 & 7 & $8^{b}$ & ac, vlh, dlh, ol, mb, p & Gliosis $(+)(\mathrm{vlh})$ \\
\hline 21 & 5 & $16^{\mathrm{b}}$ & ac, vlh, dlh, cb, mo, mb & Multifocal mononuclear infiltrate $(+)(\mathrm{dlh}, \mathrm{vlh}, \mathrm{mb})$, multifocal gliosis $(+)(\mathrm{p})$ \\
\hline 23 & 5 & $6^{c}$ & ac, vlh, dlh, mb, p & ne \\
\hline 26 & 6 & $6^{\mathrm{c}}$ & $\mathrm{ac}, \mathrm{ol}, \mathrm{cb}$ & ne \\
\hline 27 & 6 & $6^{\mathrm{c}}$ & ac, vlh, dlh, mb & ne \\
\hline 28 & 5 & $6^{\mathrm{b}}$ & $\mathrm{cb}$ & ne \\
\hline 29 & 6 & $6^{\mathrm{c}}$ & ac, vlh, cb & - \\
\hline \#3.1 & 6 & $8^{c}$ & ac, vlh, dlh, mb, p, pc, tg, ol & - \\
\hline 3.5 & 5 & $7^{\mathrm{c}}$ & ac, vlh, dlh, mb, p, pc, tg, ol, cb & Focal hemmorrhage (meninge)(dlh, vlh) \\
\hline 3.6 & 5 & $7^{\mathrm{b}}$ & ac, vlh, dlh, mb, p, pc, ol & Mononuclear inflamatory infiltrate(meninge $)(+)(\mathrm{hvl})$ \\
\hline 3.7 & 5 & $6^{\mathrm{c}}$ & $\mathrm{ac}, \mathrm{vlh}, \mathrm{mb}, \mathrm{p}, \mathrm{ol}$ & - \\
\hline 3.8 & 5 & $7^{\mathrm{c}}$ & $\mathrm{cb}, \mathrm{pc}$ & $\begin{array}{l}\text { Focal mononuclear inflamatory infiltrate(meninge })(+) \text { and perivascular } \\
\text { cuffing(vlh) }\end{array}$ \\
\hline 3.9 & 6 & $7^{\mathrm{b}}$ & ac, vlh, dlh, mb, p, tg, ol, cb & Focal mononuclear infiltrate (meninge) $(+)(\mathrm{dlh})$, focal/extense infiltrate (vlh) \\
\hline 4.0 & 5 & $7^{\mathrm{b}}$ & idem 3.5 & - \\
\hline
\end{tabular}

${ }^{a}$ ac, anterior cerebrum; pc, posterior cerebrum; vlh, ventro-lateral hemisphere; dlh, dorso-lateral hemisphere; mb, midbrain; cb, cerebellum; $p$, pons; ol, olfactorybulb; mo, medulla oblongata; tg, trigeminal ganglia; cc, cervical cord;cc, cerebral cortex. Time of the ${ }^{b}$ Death or ${ }^{c}$ Euthanasia; ${ }_{\mathrm{d}}^{\mathrm{d}}$ mild histological change $(+)$; moderate $(++)$, absence of lesion $(-) ;{ }^{\mathrm{e}}$ not examined 
was not conducted. Infectious virus was recovered from brains of all animals showing neurological signs (Tables 2 and 3). Infectivity was detected in several regions of the CNS, most consistently in the ventrolateral hemisphere and anterior cerebrum (Table 3). Other areas such as dorso-lateral hemisphere, midbrain, pons, cerebellum, olfactory lobe and medulla oblongata also frequently showed infectivity upon inoculation onto cell cultures. Posterior cerebrum, cervical cord and trigeminal ganglia only occasionally were positive for virus. Low to moderate levels of virus were found all across the brain sections examined (Table 3). The highest levels of infectivity were demonstrated in the ventro-lateral hemisphere, followed by anterior cerebrum and dorso-lateral hemisphere. Infectivity was also demonstrated in the brain of one animal found dead without previous illness (experiment \# 2). Attempts to isolate virus from brains of the animals found dead in experiment \# 4 were not conducted. Infectious virus was rarely isolated from non-neural tissues such as lungs $(1 / 13)$ and liver $(2 / 15)$ and was not recovered from spleen $(0 / 13)$ or kidney $(0 / 13)$.

Table 3. Infectivity in the central nervous system (CNS) of rabbits showing neurological signs following inoculation with bovine herpesvirus type-5 (BHV-5) strain EVI-88.

\begin{tabular}{llc}
\hline Section & \multicolumn{2}{c}{ Infectivity } \\
& Frequency (\%) & Level $^{\mathrm{a}}$ \\
\hline Anterior cerebrum & $75(15 / 20)$ & $+++^{\mathrm{b}}$ \\
Posterior cerebrum & $25(5 / 20)$ & ++ \\
Ventro-lateral hemisphere & $80(16 / 20)$ & ++++ \\
Dorso-lateral hemisphere & $50(10 / 20)$ & +++ \\
Midbrain & $55(11 / 20)$ & ++ \\
Cerebellum & $35(7 / 20)$ & ++ \\
Pons & $46(12 / 26)$ & ++ \\
Olfactory bulb & $45(9 / 20)$ & ++ \\
Medulla oblongata & $38(10 / 26)$ & + \\
Trigeminal ganglia & $20(4 / 20)$ & + \\
Cervical cord & $7.6(1 / 13)$ & + \\
\hline
\end{tabular}

${ }^{a}$ Average of virus titer determined for each tissue section obtained from several animals, ${ }^{\mathrm{b}}$ Infectivity levels: + virus titer below $10^{2} \mathrm{TCID}_{50} /$ $\mathrm{g}$ of tissue; ++ between $10^{2}$ and $10^{3} \mathrm{TCID}_{50} / \mathrm{g}$; +++ between $10^{3}$ and $10^{4} ;++++$ above $10^{4} \mathrm{TCID}_{50} / \mathrm{g}$.

Histological changes. Microscopic lesions were mild and characterized by rare foci of non-suppurative meningitis, occasional mononuclear cell infiltrates (perivascular cuffing), and focal gliosis. These changes were observed mostly in the ventro-lateral hemisphere and anterior cerebrum of some rabbits (Table 2).
Passive immunity and protection from neurological disease. Immunization of two adult female rabbits by two inoculations of the homologous BHV-5 induced moderate levels of virus-neutralizing (VN) antibodies (Table 4). None of the inoculated females developed respiratory or neurological signs. Most bunnies born to these dams also had VN antibodies at the time of the challenge, with titres ranging from 1:4 to $1: 16$ (Table 4). Rabbits born to immunized dams showed reduced morbidity $(5 / 12$ or $41.6 \%$ showed neurological signs) and mortality rates ( $7 / 12$ or $58 \%$ ) when compared with rabbits born to BHV-5 seronegative dams ( $7 / 10$ or $70 \%)$. These rates were also lower when compared with the overall mortality observed in all four inoculations (78.8\%). The onset and duration of clinical disease were also affected by passive immunity. Most animals born to immunized dams showed a significative delay in the onset of clinical disease (average 7.4 days pi) compared to animals born to non-immunized dams $(5.28 \mathrm{dpi})(\mathrm{p}<0.00038)$. These animals also showed an increased clinical period compared to the nonimmune controls (Table 4). Death or euthanasia in these animals were concentrated mostly after days 9 and 10 (average: day 11.4), comparing with death/ euthanasia in the control group (average: day $7 \mathrm{pi}$ ) $(p<0.00066)$. Additionally, two rabbits born to vaccinated dams were found dead on days 14 and 15 , without previous illness.

\section{DISCUSSION}

The results presented herein demonstrate that BHV-5 neurological infection and disease can be consistently reproduced in weanling rabbits by inoculation with a Brazilian BHV-5 isolate. Intranasal inoculation of the isolate EVI- 88 resulted in CNS infection and neurological signs in $75.8 \%$ of the inoculated animals ( $78.8 \%$ mortality). Infectious virus was recovered from several areas of the brain of animals showing neurological signs. Mild histological changes, characterized by occasional focal meningitis, mononuclear inflammatory infiltrate (perivascular cuffing) and focal gliosis were observed in CNS sections of some animals. In addition, the BHV-5induced neurological disease in rabbits proved to be useful for evaluating the protection conferred by passive immunity. Although several aspects of BHV5 infection and neurological disease in rabbits remain to be elucidated, these findings point towards the use of this species as an animal model for studying 
Table 4- Effects of passive immunity on neurological disease and mortality in rabbits inoculated with bovine herpesvirus type 5 (BHV-5) strain EVI-88.

\begin{tabular}{|c|c|c|c|c|c|c|c|}
\hline \multirow[t]{2}{*}{ Dam } & \multirow{2}{*}{$\begin{array}{l}\mathrm{VN} \\
\text { titer }\end{array}$} & \multirow{2}{*}{$\begin{array}{c}\text { Neurological } \\
\text { disease }\end{array}$} & \multirow[t]{2}{*}{ Mortality } & \multirow[t]{2}{*}{ Rabbit } & \multirow{2}{*}{$\begin{array}{l}\mathrm{VN} \\
\text { titer }\end{array}$} & \multicolumn{2}{|c|}{ Clinical Disease $\left(\mathrm{dpi}^{\mathrm{a}}\right)^{\mathrm{b}}$} \\
\hline & & & & & & Onset & $\begin{array}{c}\text { Death/ } \\
\text { euthanasia }\end{array}$ \\
\hline \multirow[t]{7}{*}{ Immunized \#1 } & $1: 32$ & $3 / 7(42.8 \%)$ & $4 / 7(57.1 \%)$ & v11 & $1: 8$ & 6 & 11 \\
\hline & & & & v12 & $1: 8$ & 7 & 10 \\
\hline & & & & v13 & $1: 8$ & $-\mathrm{c}$ & $-d$ \\
\hline & & & & v14 & $<1: 2$ & - & 15 \\
\hline & & & & v15 & $1: 4$ & - & - \\
\hline & & & & v16 & $1: 8$ & - & - \\
\hline & & & & v17 & $1: 8$ & 8 & 9 \\
\hline \multirow[t]{5}{*}{ Immunized \#2 } & $1: 64$ & $2 / 5(40 \%)$ & $3 / 5(60 \%)$ & v21 & $1: 16$ & - & - \\
\hline & & & & v22 & $1: 16$ & 8 & 10 \\
\hline & & & & v23 & $1: 8$ & 8 & 11 \\
\hline & & & & v24 & $\mathrm{nd}^{\mathrm{e}}$ & - & 14 \\
\hline & & & & v25 & $1: 8$ & - & - \\
\hline \multirow[t]{10}{*}{ Non-immunized } & $<1: 2$ & $7 / 10(70 \%)$ & $7 / 10(70 \%)$ & c 1 & $<1: 2$ & - & - \\
\hline & & & & c2 & $<1: 2$ & - & - \\
\hline & & & & c3 & $<1: 2$ & - & - \\
\hline & & & & c4 & $<1: 2$ & 6 & 7 \\
\hline & & & & c5 & $<1: 2$ & 5 & 7 \\
\hline & & & & c6 & $<1: 2$ & 5 & 7 \\
\hline & & & & c7 & $<1: 2$ & 5 & 6 \\
\hline & & & & c 8 & $<1: 2$ & 5 & 8 \\
\hline & & & & c9 & $<1: 2$ & 5 & 7 \\
\hline & & & & c 10 & $<1: 2$ & 6 & 7 \\
\hline \multirow{2}{*}{$\begin{array}{l}\text { Mock-infected/ } \\
\text { controls }\end{array}$} & & & $0 / 2$ & $\operatorname{cc} 7$ & $<1: 2$ & - & - \\
\hline & & & & $\operatorname{cc} 8$ & $<1: 2$ & - & - \\
\hline
\end{tabular}

${ }^{\text {a }}$ Day post-inoculation

b The means of the onset of clinical disease and death in the immunized and control groups were compared by the "F" test, at a significance of $1 \%$.

${ }^{c}$ Absence of clinical signs or death

${ }^{\mathrm{e}}$ Not determined

selected aspects of BHV-5 neuropathogenesis.

Extensive investigations utilizing animal models have provided important insights into the pathogenesis of neurotropic alphaherpesviruses (e.g. HSV and PRV) and contributed to the overall understanding of the alphaherpesviruses neuropathogenesis $(1,7,8,9,17$, $26,28)$. The BHV-1/BHV-5 system provides a unique opportunity to identify and to map the alphaherpesvirus gene function (s) associated with neuroinvasiveness and neurovirulence. Nevertheless, studies concerning BHV-5 neuropathogenesis have been historically hampered due to the lack of a suitable animal. Attempts to study BHV-5 neuropathogenesis in rabbits have been reported since the initial evidences of its association with meningoencephalitis in cattle $(12,13)$. The initial experimental infections, conducted by intradermal, intravenous and subcutaneous routes in adult rabbits, failed to reproduce clinical disease (13). Almost two decades later, rabbits were shown to be suitable models and have thereafter been used to study the pathogenesis and molecular aspects of BHV-1 acute and latent infections $(5,21,22)$. Experimental infections of rabbits with respiratory viruses have been classically conducted by inoculation into the conjunctival sac, due to the small size, particular anatomy and sensitivity of the nares and nasal cavity (21). The suitability of this route of inoculation to study neuropathogenesis is controversial, since it may not result in the same pathways of CNS invasion occurring in natural infections(19). The description of a technique for inoculation directly into the paranasal sinuses through trephine openings has allowed the reproduction of intranasal inoculation and infection by BHV-1 and BHV-5 in rabbits (5).

Using this technique, we initially evaluated the susceptibility of weanling rabbits to BHV-5 infection and disease by two isolates. In a first attempt, only 
the Brazilian isolate EVI-88 produced neurological disease (100\% mortality, Table 1). The Argentinean prototype strain A663 did not produce neurological signs in six inoculated rabbits (data not shown). This isolate has been shown to reproduce meningoencephalitis in calves upon experimental inoculation and recently has been used to cause neurological disease also in rabbits $(4,19,25)$. The administration of dexamethasone prior to virus inoculation, as recommended by Chowdury et al. (10), had no effect in increasing morbidity or mortality rates or severity of disease with any of the viruses tested herein. The isolate EVI 88 was then used throughout the subsequent inoculations, without previous dexamethasone treatment. A total of four inoculations were performed, with the development of neurological disease in 25/33 (75.8\%) and mortality in $26 / 33(78.8 \%)$ of the animals. The clinical signs were typical of neurological disease and consisted of episodes of excitation/depression, tremors, bruxism, incoordination, backward arching of the head and body and inevitably death. Most animals started showing clinical signs between days 5 and 6 pi and died or were euthanized within 24 to 48 hours. The onset of clinical disease occurred earlier and the clinical course was shorter than in cattle $(2$, $3,25)$, reflecting what usually happens in the mouse and rat models for PRV and HSV neuropathogenesis, respectively $(1,7,8,26,28)$. The short incubation period observed in these models has been attributed, at least in part, to the the shortest path traveled by the virus to reach the CNS of these species upon inoculation into peripheric sites (19).

The neuropathogenesis of HSV and PRV has been extensively studied in animal models as well as in their natural host for PRV $(1,7,8,9,14,15,16,17,26$, 28 ). Invasion of the CNS from peripheric sites is believed to occur primarily by transport of virus through circuits of synaptically linked neurons $(1,7$, 15). After intranasal inoculation, the main pathway to the CNS appears to be the sensory neurons of the trigeminal nerve, yet the olfactory route may also be operative $(14,16)$. This appears also to be the pathways used by BHV-1 and BHV-5 to reach the CNS of cattle $(2,3,10)$. After replication in the nasal mucosa, virions invade nerve endings and are transported by retrograde axonal transport to sensory neuron cell bodies located in the trigeminal ganglia $(14,15,16)$. Viral replication in ganglionic cell bodies is followed by anterograde transport of virions to second order neurons located in the brain stem (pons and medulla oblongata), from where virions are transported to third order neurons located in the thalamus and cerebellum. Replication in these sites is followed by viral spread within the cerebral hemispheres $(15,16)$.

In the present study, the pathway utilized by the virus to reach the CNS of rabbits could not be determined. Infectious virus was recovered from several brain sections examined in the four inoculations (Table 3). In particular, the ventro-lateral hemisphere and anterior cerebrum were most consistently infected and usually harboured the highest titers of virus. Dorso-lateral hemisphere, midbrain, pons and cerebellum were also frequently infected. Frequent infection of these areas has been also reported in natural and experimental BHV-5 infections and are believed to result from transport of virus through the trigeminal pathway $(2,3,10)$. Additionally, the frequent infection of the main olfactory bulb (MOB) $(45 \%$ or $9 / 20)$ and anterior cerebrum $(75 \%$ or $15 / 20)$ suggests that the olfactory pathways are also utilized for BHV-5 to invade the CNS of rabbits following intranasal inoculation. The olfactory pathway is the shortest route to the CNS from the nasal cavity $(1,14)$ and has been shown to represent an alternative route for HSV and PRV in mice and pigs $(1,14)$. Likewise, natural and experimental infections of cattle have also demonstrated infections of the MOB $(2,12,13)$. Recently, Meyer et al. (19) failed in detecting infectivity in the MOBs of rabbits inoculated with BHV-5 (strain N569) whereas Chowdury et al. (10) demonstrated infectivity in 8 out of 12 rabbits inoculated with a North-American BHV-5 isolate. The reasons for this discrepancy are not clear, but it may apparently result from differences in neurotropism between these viruses. The frequent MOB infection and the consistent presence of infectious virus in the anterior cerebrum observed in ours and Chowdury $\mathrm{s}$ studies strongly suggest that the olfactory pathway is an important route utilized by BHV-5 to reach the CNS of rabbits. following intranasal inoculation Despite of the severity of clinical disease and the widespread distribution of virus within the CNS of some animals, only mild to moderate histological changes were observed. The ventro-lateral hemisphere was the section that most consistently showed histological changes. These findings agreed with the consistent detection of infectivity in this section. Even though, these lesions were not constant in all brain sections examined and were observed only in some animals (Table 3 ). These findings contrast 
with findings by Meyer et al. (19) and specially by Chowdury et al.(10), in which a widespread nonsuppurative meningo-encephalitis characterized by perivascular cuffs, mononuclear infiltrates and neuronal degeneration was consistently observed in most animals. A possible explanation for this discrepancy may be the different time courses of the infection and disease among the experiments. In the present study, most animals $(76.94 \%)$ died or were euthanized up to day $7 \mathrm{pi}$, after a very fast (10 to $24 \mathrm{~h}$ ) clinical evolution. In Chowdury s study, $75 \%$ (9 out of 12) rabbits died or were euthanized between days 9 and 14 pi (average: 11.2 dpi). It is conceivable that, in most animals in the present study, a very early and massive viral invasion and replication in the CNS ensued, leading to death before a significant inflammatory response could be mounted.

A disease animal model would also be of great benefit to study the cellular and humoral mechanisms involved the immune response to alphaherpesviruses. As a preliminary study, we tested the rabbit BHV-5induced neurological disease to measure protection conferred by maternally acquired immunity. Adult rabbits are fairly resistant to $\mathrm{BHV}-5$-induced neurological disease, so the dams could be immunized by intranasal and intramuscular routes as to enhance the immune response. Likewise, the virus titers used for immunization were lower than the titers used for subsequent challenge of the bunnies. Bunnies born to these vaccinated dams showed significantly lower morbidity and mortality rates and a delay in the onset and duration of clinical disease. Although cellmediated immunity is believed to play a major role in protection against alphaherpesviruses, serum antibodies have also been shown to confer some protection (17). In our study, the delay in the clinical disease and the reduction in morbidity and mortality rates suggest that humoral immunity may also play a role in the protective immune response against BHV5. In any case, the BHV-5-induced neurological disease in rabbits may be useful to further approach these and other immunological questions, including vaccine development and testing.

The biological and molecular basis for the neuropathogenic phenotype of BHV-5 remains one of the most intriguing and interesting issues in animal virology. Among the questions awaiting investigation are:

1. How can two viruses (BHV-1 and BHV-5), almost identical at biological and molecular levels, be so distinct in one biological property that is fundamental for full expression of their phenotypes?

2. Are the differences in neuropathogenicity derived from differences in neuroinvasiveness or neurogrowth, or both?

3. At which level of the peripheral or central nervous system is the replication/invasion of BHV-1 restricted?

4. What are the gene functions differentially expressed in BHV-5 that enable it to invade, replicate and spread within the CNS? Is it possible to map and isolate these functions?

5. Is it possible to complement the gene functions lacking in BHV-1 with the homologous BHV-5 gene functions as to confer neuropathogenicity to the former?

As it has been demonstrated for PRV and HSV, the establishment of a suitable animal model will represent an hallmark towards the understanding of these and other issues concerning BHV-5 neuropathogenesis.

The results presented herein demonstrate that BHV-5-induced neurological disease can be consistently reproduced in rabbits upon inoculation with isolate EVI-88. These findings point out for a potential use of rabbits to study selected aspects of the pathogenesis of BHV-5-induced neurological disease. Nevertheless, a further characterization of rabbit infection and disease, particularly regarding to the pathway of CNS invasion, is required to better evaluate the suitability of this species as an animal model for studying BHV-5 neuropathogenesis.

\section{ACKNOWLEDGMENTS}

This work was supported by a MCT, CNPq, CAPES and FINEP grant (PRONEX em Virologia Veterinária, 215/96). E.F. Flores (352386/96), R. Weiblen (520161/97-1) and L.F. Irigoyen (523134/96-7) have scholarships from CNPq. A.M. Silva was supported by a scholarship from CAPES. We thank Antoninho Macuglia (DVM) (Biotério Central, UFSM) and Prof. Ione Terezinha Denardin (Colégio Agrícola, UFSM) for providing the rabbits for the experimental inoculations. We also thank the students in our lab for the help in taking care and handling the rabbits.

\section{RESUMO}

Patogenia da meningo-encefalite pelo herpesvírus bovino tipo 5 (HBV-5) em coelhos 
Este artigo descreve os principais aspectos da infecção e enfermidade neurológica pelo herpesvírus bovino tipo 5 (HVB-5) em coelhos. Inoculação intranasal de coelhos recém-desmamados com uma amostra brasileira do HVB-5 produziu enfermidade neurológica e mortalidade em 78,8\% (26/33) dos animais inoculados. Os sinais neurológicos iniciaram a partir do $5^{0}$ dia pós-inoculação e persistiram por 10-12 horas até vários dias. A maioria dos animais evoluiu clinicamente até um estado moribundo ou morte em $24 \mathrm{~h}(69,2 \%)$ a $48 \mathrm{~h}(88,5 \%)$. A enfermidade neurológica caracterizou-se por crises de excitabilidade/depressão, tremores, bruxismo, andar/ correr em círculos, queda para o lado e para trás, arqueamento do pescoço e corpo para trás, incoordenação, movimentos de pedalagem, depressão profunda e morte. Níveis moderados de infectividade foram detectados em várias áreas do encéfalo, principalmente no hemisfério ventro-lateral (em 16 de 20 animais), cérebro anterior (15/20), pedúnculo cerebral (11/20), hemisfério dorso-lateral (10/20) e ponte (12/26). O vírus foi também detectado no bulbo olfatório(9/20), bulbo(10/26), cerebelo $(7 / 20)$, cérebro posterior $(5 / 20)$ e gânglio trigêmeo $(4 / 20)$. Alterações macroscópicas não foram observadas. As lesões microscópicas foram discretas e consistiram de meningite multifocal, infiltrado inflamatório mononuclear perivascular e gliose focal. Essas alterações foram observadas principalmente no córtex ventro-lateral e cérebro anterior. Imunidade passiva protegeu parcialmente os animais da enfermidade neurológica. Coelhos filhos de mães imunizadas com o HVB-5 apresentaram um retardamento no início dos sinais clínicos e taxas reduzidas de morbidade e mortalidade quando comparados com coelhos filhos de mães não imunizadas. Esses resultados demonstram que a enfermidade neurológica causada pelo HVB-5 pode ser consistentemente reproduzida em coelhos e apontam para uma possível utilização dessa espécie como modelo experimental para estudar a neuropatogênese do HVB-5.

Palavras-chave: Herpesvírus bovino tipo 5, HVB-5, meningo-encefalite, modelo experimental, coelhos

\section{REFERENCES}

1. Babic, N.; Mettenleiter, T.C.; Ugolini, G.; Flammand, A.; Coulon, $P$. Propagation of pseudorabies in the nervous system of the mouse after intranasal inoculation. Virology, 204:616-625. 1994.

2. Bagust, T. J.; Clark, L. Pathogenesis of meningoencephalitis produced in calves by infectious bovine rhinotracheitis herpesvirus. J. Comp. Path. 82:375-383.1972.

3. Belknap, E.B.: Collins, J.K.; Ayers, V.K.; Schultheiss, P.C. Experimental infection of neonatal calves with neurovirulent. Vet. Pathol. 31:358-365. 1994

4. Bratanich, A.C.; Sardi, A.I.; Smitstaart, E.N.; Schudel, A.A. Comparative studies of BHV-1 variants by in vivo and in vitro tests. Zbl.Vet.Med.B. 38:41-48.1991.

5. Brown, G.A.; Field, H.J. A reliable method for establishing viral infection in the rabbit by intranasal inoculation. J. Virol. Methods. 27:341-346, 1990.

6. Bulach, D.M.; Studdert, M.J. Comparative genome mapping of bovine encephalitis herpesvirus, bovine herpesvirus 1 , and buffalo herpesvirus. Arch. Virol., 113:17-34, 1990.

7. Card, J.P., Rinaman, L., Schwaber, J.S., Miselis, R.R., Whealy, R.E., Robbins, A.K., Enquist, L.W. Neurotropic properties of pseudorabies virus: update and transneuronal passage in the rat central nervous system. J.Neurosci., 10:1974-1994, 1990.

8. Card, J.P., Whealy, M.E., Robbins, A.K., Moore, R.Y., Enquist, L.W. Two alphaherpesvirus strains are transported differentially in the rodent visual system. Neuron, 6: 957-959, 1991.

9. Card, J.P., Whealy, M.E., Robbins, A.K., Enquist, L.W. Pseudorabies virus envelope glycoprotein-gI influences both neurotropism and virulence during infection of the rat visual system. J. Virol., 66:3032-3041, 1992.

10. Chowdury, S.I., Lee, B.J., Mosier, B.J., Sur, J-H., Osorio, F.A., Kennedt, G., Weiss, M.L. Neuropathology of bovine herpesvirus type 5 (BHV-5) meningoencephalitis in a rabbit seizure model. J.Comp.Pathol.,117:295-310.1997.

11. Friedli, K.; Metzler, A.E. Reactivity of monoclonal antibodies to proteins of a neurotropic bovine herpesvirus 1 (BHV-1) strain and to proteins of representative BHV-1 strains. Arch. Virol., 94:109-122, 1987

12. French, E. L. A specific virus encephalitis in calves: isolation and characterization of the causal agent. Aust.Vet.J., 38:216221.1962.

13. Hall, W.T.K., Simmons, G.C., French, E.L., Snowdon, W.A., Asdell, M. The pathogenesis of meningoencephalitis caused by the infectious bovine rhinotracheitis virus. Aust.Vet.J. 42:229237.1966.

14. Jacobs, L., Mulder, W.A.M., Van Oirschot, J.T., Gielken, A.L.; Kimman, T.G. Deleting two aminoacidos in glycoprotein gI of pseudorabies virus decreases virulence and neurotropism for pigs, but does not affect immunogenicity. J.Gen.Virol. 74:22012206.1993.

15. Kritas, S.K., Pensaert, M.B.; Mettenleiter, T.C. Invasion and spread of single glycoprotein deleted mutants of Aujeskyïs disease virus (ADV) in the trigeminal nervous pathway of pigs after intranasal inoculation. Vet.Microbiol. 40:323-334.1994.

16. Kritas, S.K., Nauwynck, H.J.; Pensaert, M.B. Dissemination of wild-type, gC-, gE- and gI-deleted mutants of Aujeszkyïs disease virus in the maxillary nerve and trigeminal ganglion of pigs after intranasal inoculation. J.Gen.Virol. 76:2063-2066.1995.

17. McKendall, R.R., Klassen, T., Baringer, J.R. Host defenses in herpes simplex infections of the nervous system: effect of antibody on disease and viral spread. Infect.Immun. 23:305311.1979 .

18. Metzler, A.E., Schudel, A.A.; Engels, M.. Bovine herpesvirus 1: molecular and antigenic characteristics of variant viruses isolated from calves with neurological disease. Arch.Virol. 87:205-217.1986. 
19. Meyer, G.; Lemaira, M.; Lyaku, J. Establishment of a rabbit model for bovine herpesvirus type 5 neurological acute infection. Vet.Microbiol. 51:27-40.1996.

20. Reed, L.; Muench, H.A simple method of estimating fifty percent endpoints. Am.J.Hyg. 18: 493-494. 1938.

21. Rock, D.L.; Reed, D.E. Persistent infection with bovine herpesvirus type-1: rabbit model. Infect.Immun., 35:371-373,1982.

22. Rock, D.Latent infection with bovine herpesvirus type-1. Semin.Virol. 5:233-240. 1994

23. Roehe, P.M., Silva, T.C., Nardi, N.B., Oliveira, D.G.; Rosa, J.C.A. Diferenciação entre o vírus da rinotraqueíte infecciosa bovina (BHV-1) e o herpesvírus da encefalite bovina (BHV-5). Pesq.Vet.Bras. 17:41-44. 1997.

24. Roizman, B. 1992. The family Herpesviridae: an update. Arch.Virol. 123:432-445
25. Schudel, A.A., Carrillo, B.J., Wyler, R.; Metzler, A.E. Infections of calves with antigenic variants of bovine herpesvirus 1 (BHV - 1) and neurological disease. Zbl.Vet.Med.B. 33:303-310. 1986.

26. Stevens, J.G. Defining herpes simplex genes involved in neurovirulence and neuroinvasiveness. Curr. Eye Res., 6:63-67, 1987.

27. Studdert, M. J.. Bovine encephalitis herpesvirus. Vet.Rec. 125:584.1989

28. Thompson,R.L.; Rogers, S.K. Zerhusen, M.A. Herpes simplex virus neurovirulence and productive infection of neural cells is associated with a function which maps between 0.82 and 0.832 map units on the HSV genome. Virology, 172:435-450, 1989.

29. Wirth, U. V. Comparison of immediate-early transcripts among bovine herpesvirus type 1 and type 5 strains differing in neurovirulent potential. Virus Res. 27:1-12, 1993. 